\title{
TEKANAN KETAATAN BUDGETARY SLACK (PERSPEKTIF BUDAYA ORGANISASI SEBAGAI VARIABEL MODERASI)
}

\author{
Lalu M. Syahril Majidi'1, Heni Agustina², Rizki Amalia Elfita ${ }^{3}$, Ninnasi Muttaqiin ${ }^{4}$ \\ Universitas Nahdlatul Ulama Surabaya syahrilmjd@unusa.ac.id, heni@unusa.ac.id, \\ elfita@unusa.ac.id, m.ninnasi@unusa.ac.id
}

\begin{abstract}
Abstrak: Setiap perusahaan saling bersaing untuk melakukan yang terbaik dalam melakukan penganggaran dan kegiatan operasional lainnya. Namun hal tersebut justru membuat para manajemen dapat melakukan kesenjangan dalam membuat anggaran. Pentingnya suatu pengelolaan anggaran ini membuat banyak manajemen melakukan budgetary slack. Faktor yang dapat mempengaruhi adanya slack salah satunya adalah tekanan ketaatan pada suatu perusahaan. Bedasarkan hal tersebut peneliti ingin mengetahui seberapa besar pengaruh tekanan ketaatan terhadap budgetary slack yang dimoderasi oleh budaya organisasi. Penelitian ini bersifat kuantitatif deskriptif dengan populasi seluruh mahasiswa yang telah mengampu mata kuliah etika profesi dan bisnis. Jumlah sampel ditemukan sebanyak 110mahasiswa. Berdasarkan hasil pengolahan data dan hasil analisisis menunjukkan bahwasannya variabel tekanan ketaatan memiliki pengaruh signifikan terhadap budgetary slack dan variabel budaya organisasi memoderasi hubungan tekanan ketaatan terhadap budgetary slack.
\end{abstract}

Kata kunci: Tekanan Ketaatan, Budgetary Slack, Budaya Organisasi

\section{PENDAHULUAN}

Anggaran merupakan alat untuk membuat perencanaan perusahaan dalam bentuk nilai kuantitatif dan diungkapkan dalam satuan moneter (Utami, 2012). Dalam prosesnya, anggaran dapat melibatkan banyak pihak; mulai dari tingkat manajemen atas hinggamanajemen bawah. Untuk memudahkan pembuatan anggaran, perlu diperhatikan faktor tekanan ketaatan dan budaya organisasi.

Pentingnya suatu pengelolaan anggaran ini membuat banyak manajemen melakukan budgetary slack. Menurut Hobson (2011) budgetary slack terjadi ketika kapabilitas dalam unit bisnis dikecilkan anggarannya. Budgetary slack merupakan adanya perbedaan antara anggaran yang telah diajukan oleh bawahan dan anggaran yang terealisasi pada pelaporan anggaran tersebut (Anthony, 2007). Faktor yang dapat mempengaruhi adanya slack salah satunya adalah tekanan ketaatan pada suatu perusahaan.

Young (1985) dan Merchant (1985) mengatakan bahwa secara empiris budgetary slack terjadi karena adanya bawahan yang memberikan informasi yang salah kepada atasan dengan membuat biaya lebih besar dari pendapatannya. Penelitian tersebut juga mengemukakan hasil bahwa dengan keinginan menghidari risiko, bawahan yang terlibat dalam pembuatan laporan akan cenderung melakukan budgetary slack.

Hasil penelitian yang berbeda dengan penelitian di atas, DeZoort dan Lord (1994) menjelaskan bahwa terdapat indikasi adanya pengaruh dari tekanan atasan tentang judgement yang diambil 
pada auditor pemula. Ditambah dengan beberapa hasil penelitian yang menyatakan perbedaan hasil yaitu terdapat indikasi bahwa slack dapat diciptakan karena kemauan seorang manager tingkat menengah dengan menekan manajer tingkat bawah agar melakukan perintah sesuai permintaan atasan. Fenomena yang hingga saat ini sedang terjadi dalam realitas kehidupan dan dunia kerja memperlihatkan bahwa bawahan akan cenderung mematuhi dan melaksanakan pekerjaan yang diperintahkan atasan langsung. Evaluasi mengenai kerentanan terhadap tekanan ketaatan bagi seorang akuntan untuk menciptakan budgetary slack dengan tidak mematuhi setiap aturan yang ada pada suatu perusahaan (Davis et al. 2006). Penelitian lain juga menyebutkan bahwa kurangnya tanggung jawab padapartisipan dapat menambah slack pada suatu keputusan dalam membuat anggaran.

Pentingnya budaya organisasi, tekanan ketaatan dalam menentukan budget sehingga tidak menimbulkan budgetary slack ini membuat penulis ingin meneliti lebih lanjut keterkaitan antar variabel tersebut.

\section{METODOLOGI}

Populasi dalam penelitian ini adalah mahasiswa S1 Akuntansi Fakultas Ekonomi Bisnis Teknologi Digital Universitas Nahdlatul Ulama Surabaya yang telah mengambil mata kuliah etika profesi dan bisnis. Argumen penggunaan mahasiswa sebagai subjek dalam penelitian ini karena mahasiswa dapat dijadikan proksi dengan asumsi bahwa mahasiswa akuntansi yang telah mengambil mata kuliah akuntansi managemen mampu memberikan keputusan etis dalam menilai budgetary slack sebagai suatu tindakan etis atau tidak etis.

Sampel penelitian menggunakan judgement sampling dari semester 3 sampai semester 8 pada tahun 2020/2021 yang telah mengambil mata kuliah etika profesi dan bisnis. Jumlah sampel sebanyak 110 mahasiswa. Menggunakan data primer dengan cara survey lapangan melalui kuesioner skala likert 1 sampai 5.

\section{A. Definisi Operasional dan Pengukuran Variabel}

\section{Variabel dependen}

Variabel dependen adalah budgetary sack. Budgetary slack merupakan suatukegiatan yang disengaja untuk menyimpangkan target kinerja berdasarkan tingkat yang telah di inginkan oleh bawahan (Hartmann dan Maas, 2010).

\section{Variabel Independen}

Penelitian ini menggunakan tekanan ketaatan sebagai variabel independen. Hartanto dan Indra (2001) mengatakan bahwa teori ketaatan adalah suatu individu yang memiliki kekuasaan merupakan suatu sumber yang dapat mempengaruhi perilaku individu dikarenakan memiliki suatu kekuasaan atas otoritas dalam bentuk legitimate power untuk mempengaruhi bawahan karena posisi khusus dalam struktur hierarki organisasi.

\section{Variabel Moderasi}

Penelitian ini menggunakan budaya organisasi sebegai variebel moderasi. Sugiwardani (2012) menyatakan bahwa budaya organisasi merupakan kumpulan dari sikap, cara pandang, kebiasaan dalam menanggapi situasi yang dapat mendorong komitmen karyawan. 
B. Analisis Data

1. Uji Kualitas Data

Untuk menguji kualitas data dilakukan dengan uji reliabilitas dan ujivaliditas.

\section{Evaluasi Model Pengukuran WarpPLS}

Evaluasi model dalam PLS meliputi 2 tahap, yaitu dengan menggunakan evaluasi Outer Model atau yang disebut dengan model pengukuran dan evaluasi Inner Model atau yang disebut dengan model struktural.

\section{Uji Hipotesis}

Dasar yang digunakan dalam pengambilan keputusan yaitu :

$p$-value $\geq 0,05$ maka Ho diterima

p-value $\leq$ 0,05 maka Ho ditolak dan $\mathrm{Ha}$ diterima.

Hipotesis 1: Tekanan ketaatan berpengaruh signifikan terhadap budgetary slack.

Hipotesis 2: Budaya organisasi memoderasi hubungan antara Tekanan ketaatan terhadap budgetary slack.

\section{HASIL DAN PEMBAHASAN}

\section{A. Evaluasi Model Pengukuran (Outer Model)}

Evaluasi outer model yang dilakukan melalui 3 kriteria yaitu convergentvalidity, discriminant validity, dan composite reliability. Berikut ini adalah hasil pengolahan data :

\section{Convergent Validity (Validasi Konvergen)}

Convergent validity dari variable dan dari model pengukuran dapat dilihat dari korelasi antara skor indikator dengan skor konstruknya (loading factor) dengan kriteria nilai loading factor dari setiap indikator lebih besar dari 0.70 dapat dikatakan valid, dan untuk nilai p-value nya apabila $<0.05$ di anggap signifikan.
Tabel 1. Hasil Output Combine Loading andCross Loading

\begin{tabular}{|c|c|c|c|c|c|c|c|}
\hline & $\mathrm{x}$ & $\mathrm{Y}$ & Z & $Z^{*} x$ & Type (as defined) & SE & Pvalue \\
\hline$x .1$ & $(0.093)$ & 0.505 & -0.249 & 0.293 & Reflective & 0.093 & 0.161 \\
\hline$x .2$ & $(0.809)$ & 0.128 & -0.142 & 0.093 & Reflective & 0.077 & $<0.001$ \\
\hline$x .3$ & $(0.785)$ & -0.181 & 0.115 & -0.047 & Reflective & 0.078 & $<0.001$ \\
\hline$x .4$ & $(0.794)$ & -0.011 & 0.060 & -0.082 & Reflective & 0.078 & $<0.001$ \\
\hline y. 1 & 0.210 & $(0.343)$ & 0.207 & -0.230 & Reflective & 0.087 & $<0.001$ \\
\hline$y .2$ & -0.133 & $(0.274)$ & 0.239 & -0.241 & Reflective & 0.089 & 0.001 \\
\hline$y .3$ & 0.006 & $(0.488)$ & -0.099 & -0.165 & Reflective & 0.084 & $<0.001$ \\
\hline y. 4 & -0.102 & $(0.717)$ & -0.111 & 0.157 & Reflective & 0.079 & $<0.001$ \\
\hline y. 5 & 0.093 & $(0.707)$ & -0.179 & -0.030 & Reflective & 0.079 & $<0.001$ \\
\hline$y .6$ & -0.061 & $(0.505)$ & 0.234 & 0.266 & Reflective & 0.084 & $<0.001$ \\
\hline z.1 & 0.138 & -0.141 & $(0.729)$ & -0.212 & Reflective & 0.079 & $<0.001$ \\
\hline$z .2$ & -0.173 & -0.231 & $(0.324)$ & -0.153 & Reflective & 0.088 & $<0.001$ \\
\hline 2.3 & -0.119 & 0.289 & $(0.590)$ & 0.208 & Reflective & 0.082 & $<0.001$ \\
\hline$z .4$ & 0.040 & 0.011 & $(0.650)$ & 0.126 & Reflective & 0.081 & $<0.001$ \\
\hline$Z^{*} x$ & 0.000 & 0.000 & 0.000 & $(1.000)$ & Reflective & 0.074 & $<0.001$ \\
\hline
\end{tabular}

Sumber : Hasil Output WarpPLS 7.0 (2021)

Hasil pengolahan data yang tampak pada tabel 1 menyimpulkan bahwa:

\section{a. Convergent Validity untuk Konstruk Tekanan Ketaatan (X)}

Dalam penelitian ini varibael Tekanan Ketaatan memliki empat indikator yaitu dalam pengolahan data di jadikan X1, X2, X3 dan X4. Berdasarkan tabel 1 hasil dari pengolahan data menunjukkan variable

Tekanan Ketaatan dengan indikator X1 memiliki nilai loading 0.093 dan nilai p-value sebesar 0.161 yang artinya tidak memenuhi kriteria convergent validity. hal tersebut dikarenakan nilai loading lebih kecil dari 0.7 dan nilai p-value lebih besar dari 0.05. Untuk indikator X2, X3 dan X4 sudah memenuhi kriteria convergent validity karena nilai loading dari indikator X2, X3, dan X4 memiliki nilai loading lebih besar dari 0.7 dan nilai p-value lebih kecil dari 0.05 .

\section{b. Convergent Validity untuk Konstruk Budgetary Slack (Y)}

Dalam penelitian ini varibael Budgetary Slack memiliki enam indikatoryaitu dalam pengolahan data di jadikan Y1, Y2, Y3, Y4, Y5 dan Y6. Berdasarkan tabel 1, hasil dari pengolahan data menunjukkan variable Budgetary Slack dengan indikator Y1 memiliki nilai 
loading 0.343 dan nilai p-value sebesar $<0.001$ yang artinya tidak memenuhi kriteria convergent validity. Hal tersebut dikarenakan nilai loading lebih kecil dari 0.7 dan indikator dari Y2 memiliki nilai loading 0.274 dan nilai p-value sebesar 0.001 yang artinya tidak memenuhi kriteria convergent validity. Untuk indikator Y3, Y4, Y5 dan Y6 sudah memenuhi kriteria convergent validity karena nilai loading dari indikator Y3, Y4, Y5 dan Y6 memiliki nilai loading lebih besar dari 0.4 dan nilai p-value lebih kecil dari 0.05 .

\section{c. Convergent Validity untuk Konstruk Budaya Organisasi (Z)}

Dalam penelitian ini varibael Budaya Organisasi (Z) memiliki empat indikator yaitu dalam pengolahan data di jadikan Z1, Z2, Z3 dan Z4. Berdasarkan tabel 1, hasil dari pengolahan data menunjukkan variable Budaya Organisasi dengan indikator Z2 memiliki nilai loading 0.324 dan nilai p-value sebesar $<0.001$ yang artinya tidak memenuhi kriteria convergent validity. Hal tersebut dikarenakan nilai loading lebih kecil dari

0.4. Untuk indikator Z1, Z3 dan Z4 sudah memenuhi kriteria convergent validity hal ini dikarenakan nilai loading dari indikator Z1, Z3 dan Z4 memiliki nilai loading lebih besar dari 0.4 dan nilai pvalue lebih kecil dari 0.05 .

\section{d. Convergen Validity untuk Kostruk Budaya Organisasi dalam Memoderasi Tekanan Ketaatan}

Dalam penelitian ini, varibel Budaya Organisasi (Z) sebagai variabel moderasi anatar variabel $\mathrm{X}$ terhadap variabel $\mathrm{Y}$. Variabel Budaya Organisasi dalam penelitian ini memiliki empat indikator yaitu dalam pengolahan data dijadikan Z1, Z2, Z3 dan Z4. Berdasarkan tabel 1, hasil dari pengolahan data menunjukkan variable Budaya Organisasi dalam memoderasi variabel Tekanan Ketaatan memiliki nilai loading sebesar 1.000 dan dengan nilai p-value sebesar $<0.001$ yang artinya variabel Budaya Organisasidalam memoderasi variabel Tekanan Ketaatan memenuhi kriteria convergent validity.

\section{e. Kriteria Nilai AVE (Average Variance Extracted)}

Pengukuran lainnya dari convergent validity adalah dengan melihat nilai AVE (Average Variance Extracted). Menurut Latan Ghozali (2017), nilai AVE harus direkomendasikan lebih besar dari 0.50 yang mempunyai arti bahwa $50 \%$ atau lebih variance dari indikator dapat dijelaskan.

Tabel 2. Hasil Nilai AVE (Average Variance Extracted)

\begin{tabular}{|c|c|c|c|}
\hline \multicolumn{4}{|c|}{ Average Variance Extracted (AVE) } \\
\hline $\begin{array}{c}\text { Varibel } \\
\text { Laten }\end{array}$ & Nilai AVE & Kriteria & Keterangan \\
\hline $\mathrm{X}$ & 0.691 & $>0.50$ & Memenuhi connergent validity \\
\hline $\mathrm{Y}$ & 0.532 & $>0.50$ & Memenuhi connergent validity \\
\hline $\mathrm{Z}$ & 0.593 & $>0.50$ & Memenuhi convergent validity \\
\hline $\mathrm{Z} * \mathrm{X}$ & 1.000 & $>0.50$ & Memenuhi connergent validity \\
\hline
\end{tabular}

Sumber : Hasil Output WarpPLS 7.0 (2021)

Berdasarkan tabel 2, keempat konstruk telah memenuhi convergent validity. Hal ini dikarenakan nilai AVE pada setiap variabel lebih dari $>0.50$.

\section{f. Standard Error}

Standard error yang besar menunjukkan model yang disusun adalah tidak layak. Nilai standard error diharapkan relatif kecil yaitu di bawah 0,5 atau 0,4 dan tidak boleh bernilai negatif. 
Tabel 3. Standard Error

\begin{tabular}{|c|c|c|c|}
\hline & $\begin{array}{c}\mathrm{SE} \\
\text { (Standard Error) }\end{array}$ & Kriteria & Keterangan \\
\hline $\mathrm{XI}$ & 0.093 & \multirow{15}{*}{$\begin{array}{c}<0.5 \text { atau }<0.4 \\
\text { dan tidak } \\
\text { negatif }\end{array}$} & Memenuhi kelayakan model \\
\hline $\mathrm{X} 2$ & 0.077 & & Memenuhi kelayakan model \\
\hline $\mathrm{X3}$ & 0.078 & & Memenuhi kelayakan model \\
\hline $\mathrm{X} 4$ & 0.078 & & Memenuhi kelayakan model \\
\hline YI & 0.087 & & Memenuhi kelayakan model \\
\hline$\overline{Y 2}$ & 0.089 & & Memenuhi kelayakan model \\
\hline Y3 & 0.084 & & Memenuhi kelayakan model \\
\hline Y4 & 0.079 & & Memenuhi kelayakan model \\
\hline Y5 & 0.079 & & Memenuhi kelayakan model \\
\hline Y6 & 0.084 & & Memenuhi kelayakan model \\
\hline$\overline{Z l}$ & 0.079 & & Memenuhi kelayakan model \\
\hline $\mathbf{Z 2}$ & 0.088 & & Memenuhi kelayakan model \\
\hline $\mathbf{Z 3}$ & 0.082 & & Memenuhi kelayakan model \\
\hline $\mathbf{Z 4}$ & 0.081 & & Memenuhi kelayakan model \\
\hline $\mathrm{Z}^{*} \mathrm{X}$ & 0.074 & & Memenuhi kelayakan model \\
\hline
\end{tabular}

Sumber : Hasil Output WarpPLS 7.0 (2021)

Berdasarkan tabel 3, dapat disimpulkan bahwa dari seluruh indikator dari masing-masing variabel penelitian ini telah memenuhi kriteria standard error yaitu kurang dari 0,5. Hal tersebut bermakna semuanya telah memenuhi kelayakan model.

\section{Discriminant Validity (Validitas Diskriminan)}

Discriminant validity dinilai dari cross loading pengukuran dengan konstruk. Terdapat dua cara untuk mengevaluasi terpenuhnya validitas deskriminan yaitu dengan cara : (1) dengan melihat loading konstruk laten, yang digunakan untuk memprediksi indikatornya lebih baik daripada konstruk lainnya. Apabila korelasi konstruk dengan pokok pengukuran (setiap indikator) lebih besar dari pada ukuran konstruk lainnya maka validitas diskriminan terpenuhi.

Untuk dapat menganalisis discriminant validity yaitu dengan kriteria AVE. Mahfud Sholihin dan Dwi Ratmono (2013) menjelaskan bahwa kriteria yang digunakan adalah akar kuadrat (square roots) Average Variance Extracted (AVE) yaitu kolom diagonal dan yang diberi tanda kurung harus lebih tinggi dari korelasi antara variable laten pada kolom yang sama (atas atau bawahnya).

\section{a. Melihat Loading ke Konstruk Lain}

Dibawah ini merupakan hasil output olah data WarpPLS 7.0 yang disajikandalam tabel 4.

Tabel 4. Nilai Loading Konstruk Laten Indikator Ke Konstruk Lainnya

\begin{tabular}{|c|c|c|c|c|c|c|}
\hline \multirow[t]{2}{*}{ Indikator } & \multirow[t]{2}{*}{ Loading } & \multicolumn{4}{|c|}{$\begin{array}{c}\text { Nilai Loading ke Konstruk } \\
\text { Lainnya }\end{array}$} & \multirow[t]{2}{*}{ Keterangan } \\
\hline & & $\mathbf{x}$ & $\mathbf{Y}$ & $\mathbf{Z}$ & $\mathbf{Z}^{\star} \mathbf{X}$ & \\
\hline $\mathrm{X} 1$ & 0.093 & & 0.505 & -0.249 & 0.293 & $\begin{array}{l}\text { idak memenuhi } \\
\text { discriminant validity }\end{array}$ \\
\hline $\mathrm{x} 2$ & 0.809 & & 0.128 & -0.142 & 0.093 & $\begin{array}{l}\text { Temenuhi discriminant } \\
\text { validity }\end{array}$ \\
\hline $\mathrm{x} 3$ & 0.785 & & -0.181 & 0.115 & 0.047 & $\begin{array}{l}\text { lemenuhi discriminant } \\
\text { validity }\end{array}$ \\
\hline $\mathrm{X} 4$ & 0.794 & & -0.011 & 0.060 & 0.082 & $\begin{array}{l}\text { lemenuhi discriminant } \\
\text { validity }\end{array}$ \\
\hline Y1 & 0.343 & 0.210 & & 0.207 & 0.230 & $\begin{array}{l}\text { emenuhi discriminant } \\
\text { validity }\end{array}$ \\
\hline Y2 & 0.274 & -0.133 & & 0.239 & 0.241 & $\begin{array}{l}\text { lemenuhi discriminant } \\
\text { validity }\end{array}$ \\
\hline Y3 & 0.488 & 0.006 & & -0.099 & 0.165 & $\begin{array}{l}\text { lemenuhi discriminant } \\
\text { validity }\end{array}$ \\
\hline Y4 & 0.717 & -0.102 & & -0.111 & 0.157 & $\begin{array}{l}\text { lemenuhi discriminant } \\
\text { validity }\end{array}$ \\
\hline Y5 & 0.707 & 0.093 & & -0.179 & 0.030 & $\begin{array}{l}\text { femenuhi discriminant } \\
\text { validity }\end{array}$ \\
\hline Y6 & 0.505 & -0.061 & & 0.234 & 0.266 & $\begin{array}{l}\text { lemenuhi discriminant } \\
\text { validity }\end{array}$ \\
\hline $\mathrm{Z1}$ & 0.729 & 0.138 & -0.141 & & 0.212 & $\begin{array}{l}\text { Temenuhi discriminant } \\
\text { validity }\end{array}$ \\
\hline $\mathrm{Z} 2$ & 0.324 & -0.173 & -0.231 & & 0.153 & $\begin{array}{l}\text { lemenuhi discriminant } \\
\text { validity }\end{array}$ \\
\hline Z3 & 0.590 & -0.119 & 0.289 & & 0.208 & $\begin{array}{l}\text { Temenuhi discriminant } \\
\text { validity }\end{array}$ \\
\hline $\mathrm{Z} 4$ & 0.650 & 0.040 & 0.011 & & 0.126 & $\begin{array}{l}\text { femenuhi discriminant } \\
\text { validity }\end{array}$ \\
\hline$Z^{*} \mathrm{X}$ & 1.000 & 0.000 & 0.000 & 0.000 & & $\begin{array}{l}\text { emenuhi discriminant } \\
\text { validity }\end{array}$ \\
\hline
\end{tabular}

Berdasarkan tabel 4, dari keseluruhan indikator; ada satu indikator yang tidak memenuhi kriteria discriminant validity. Hal tersebut dikarenakan nilai loading lebih kecil darinilai konstruk lainnya.

\section{b. Metode kedua (Kriteria AVE)}

Metode AVE ini dapat dilakukan dengan melihat kriteria dari AVE. AVE di dalam kolom diagonal dan diberi tanda kurung harus lebih tinggi dari korelasi antar variable laten pada kolom yang sama (atas atau bawahnya).

Tabel 5. Hasil Output Correlation Among Latent Variable

Correlations among I.vs. with sq. rts. of AVEs
\begin{tabular}{|c|l|l|l|l|}
\hline \multicolumn{1}{|c|}{ X } & \multicolumn{1}{|c|}{ Y } & \multicolumn{1}{c|}{ Z } & \multicolumn{1}{c|}{$Z^{*}$ X } \\
\hline X & $(0.691)$ & 0.260 & 0.207 & 0.026 \\
\hline Y & 0.260 & $(0.532)$ & 0.223 & -0.108 \\
\hline$Z$ & 0.207 & 0.223 & $(0.593)$ & 0.125 \\
\cline { 1 - 1 }$Z^{*} X$ & 0.026 & -0.108 & 0.125 & $(1.000)$ \\
\hline
\end{tabular}

Sumber : Hasil Output WarpPLS 7.0 (2021) 
Berdasarkan tabel 5, keseluruhan indikator bisa dikatakan memenuhi kriteria discrimant validity. Hal tersebut dikarenakan nilai AVE yang ada di dalam kolom diagonal lebih tinggi dari korelasi antar variabel laten pada kolom yang sama (yaitu kolom atas atau bawahnya).

\section{Composite Relibility}

Pengajuan dalam tahap selanjutnya adalah uji realibilitas konstruk yang dapat diukur dengan menggunakan 2 kriteria yaitu composite reliability dan cronbach's alpha. Suatu konstruk dapat dikatakan reliabel apabila nilai composite realibility $>0,70$.

Tabel 6. Output Latent Varible Coefficient

\begin{tabular}{|c|c|c|c|c|}
\hline & $\mathrm{X}$ & $\mathrm{Y}$ & $\mathrm{Z}$ & $\mathrm{Z}^{*} \mathrm{X}$ \\
\hline R-Squared & & 0.103 & & \\
\hline Composite reliab & 0.746 & 0.682 & 0.670 & 1.000 \\
\hline Cronbach's Alpha & 0.562 & 0.459 & 0.362 & 1.000 \\
\hline Avg. var. extrac & 0.477 & 0.283 & 0.352 & 1.000 \\
\hline Full Collin. VIF & 1.101 & 1.132 & 1.104 & 1.037 \\
\hline Q-squared & & 0.108 & & \\
\hline
\end{tabular}

Sumber : Hasil Output WarpPLS 7.0 (2021)

Tabel 6 menunjukkan bahwa composite reliability dari masing-masing konstruk yaitu (X) 0.746, (Y) 0.682, (Z) 0.670, dan $\left(Z^{*} X\right)$ 1.000. Berdasarkan nilainya, dapat disimpulkan

bahwasannya hasil dari composite reliability dari keseluruhan variabel ada dua variabel yang tidak memenuhi kriteria composite realibility. Hal tersebut dikarenakan nilai dari kedua variabel $\mathrm{X}$ dan $\mathrm{Z}$ lebih kecil dari kriteria yang ditentukan yakni sebesar >0,70. Hasil dari cronbach's alpha dari masing-masing konstruk yaitu, (X) 0.562, (Y) 0.459, (Z) 0.362, dan $\left(Z^{*} X\right)$ 1.000. Berdasarkan hasil uraian tersebut dapat disimpulkan bahwa hasil dari cronbach's alpha dari semua variabel sudah memenuhi kriteria cronbach's alpha.

\section{B. Evaluasi Model Struktural (Inner Model)}

Evaluasi model struktural (inner model) yang meliputi uji kecocokan model (model fit), path coefficient, dan $\mathrm{R}^{2}$. Pada uji kecocokan model terdapat 3 indeks pengujian yaitu, average path coefficient (APC), average $R$-squared (ARS) dan average varians factor (AVIF) dengan kriteria APC dan ARS diterima dengan syarat $p$-value $<0.05$ dan AVIF lebih kecil dari 5 (Mahfud Sholihin dan Dwi Ratmono, 2013).

\section{Tabel 7. Output General SEM Analysis Result}

Model fit and quality indices

$\mathrm{APC}=0.188, \mathrm{P}=0.010$

ARS $=0.103, \mathrm{P}=0.068$

AVIF $=1.251$, Good if $<5$

Sumber : Hasil Output WarpPLS 7.0 (2021)

Hasil pada tabel 7 menjelaskan bahwa APC memiliki nilai indeks sebesar

0.188 dengan nilai p-value 0.010. Nilai indeks ARS sebesar 0.103 dengan nilai pvalue 0.068. Berdasarkan kriteria APC dan ARS, nilai APC diterima dan nilai ARS ditolak. Hal ini dikarenakan nilai P-Value ARS lebih besar dari 0.05. Akan tetapi hasil nilai AVIF diterima karena nilai AVIF lebih kecil dari 5 dan bisa dinyatakan dengan hasil Good If.

\section{Hasil Uji Hipotesis}

Hasil korelasi antar konstruk dapat diukur dengan melihat path coefficient dan tingkat signifikannya yang kemudian dibandingkan dengan hipotesis penelitian. Tingkat siginifikan yang dipakai dalam penelitian ini adalah sebesar $5 \%$. 
Hipotesis 1 : Tekanan ketaatan berpengaruh signifikan terhadap budgetary slack

Hipotesis 2 : Budaya organisasi memoderasi hubungan antara Tekanan ketaatan terhadap budgetary slack

Berikut ini merupakan gambar model penelitian dan hasil dari effect size yang telah diperoleh berdasarkan pengolahan data sebagai berikut :

Gambar 1. Model Penelitian

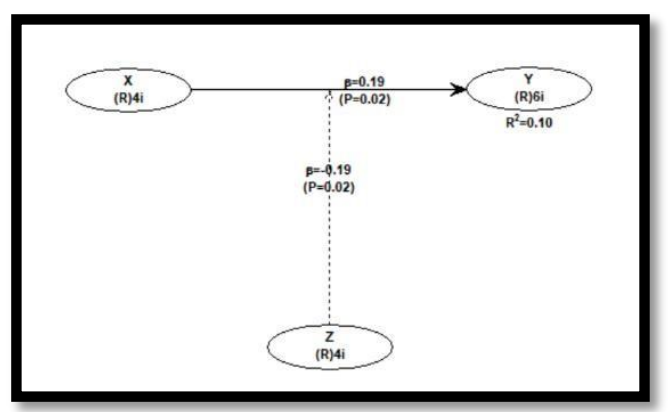

(Sumber : Hasil Output WarpPLS 7.0 (2021))

Angka pada gambar di atas merupakan pembulatan dari Path Coefficient dan PValue

Keterangan gambar 1 :

$\begin{array}{ll}\mathrm{X} & \text { : Tekanan Ketaatan } \\ Y & \text { : Budgetary Slack } \\ \mathrm{Z} & \text { : Budaya Organisasi }\end{array}$

Berikut ini merupakan data disajikan dalam bentuk tabel sebagai berikut:

Tabel 8. Direct Effect

\begin{tabular}{|c|c|c|c|c|c|}
\hline Kriteria & Variabel & $\mathbf{X}$ & $\mathbf{Y}$ & $\mathbf{Z}$ & $\mathbf{Z}^{*} \mathbf{X}$ \\
\hline \multirow{4}{*}{ Path Coefficient } & $\mathbf{X}$ & & & & \\
\hline & $\mathbf{Y}$ & 0.192 & & & -0.185 \\
\hline & $\mathbf{Z}$ & & & & \\
\hline & $\mathbf{Z}^{*} \mathbf{X}$ & & & & \\
\hline \multirow{4}{*}{$\boldsymbol{P}$-Value } & $\mathbf{X}$ & & & & \\
\cline { 2 - 6 } & $\mathbf{Y}$ & 0.018 & & & 0.022 \\
\hline & $\mathbf{Z}$ & & & & \\
\hline & $\mathbf{Z}^{*} \mathbf{X}$ & & & & \\
\hline \multirow{3}{*}{ Effect Sizes for Path } & $\mathbf{X}$ & & & & \\
\cline { 2 - 6 } & $\mathbf{Y}$ & 0.053 & & & 0.050 \\
\hline & $\mathbf{Z}$ & & & & \\
\hline & $\mathbf{Z}^{*} \mathbf{X}$ & & & & \\
\hline
\end{tabular}

Sumber : Hasil Output WarpPLS 7.0 (2021)
Berikut ini merupakan pengujian hipotesis yang diuraikan lebih lanjut sebagai berikut :

\section{Uji Hipotesis 1}

\section{a. Hipotesis}

Ho : Tekanan ketaatan berpengaruh tidak signifikan terhadap budgetary slack

Ha : Tekanan ketaatan berpengaruh signifikan terhadap budgetary slack

\section{b. Dasar Pengambilan Keputusan}

P-Value $\geq 0.05$, maka Ho di tolak $\mathrm{P}$-Value $<0.05$, maka Ho di totaldan $\mathrm{Ha}$ diterima

\section{c. Keputusan}

P-Value $=0.018<0.05$ maka Hoditolak dan Ha diterima

\section{d. Kesimpulan dan Pembahasan}

Kesimpulan dari uji hipotesis 1 adalah variabel Tekanan ketaatan memiliki pengaruh yang signifikan terhadap budgetary slack. Hal ini bermakna bawahan seringkali merasa apa yang dilakukan di tempat kerja harus berdasarkandengan arahan dari atasan. Ketika atasan meminta untuk melakukan tindakan tertentu pada anggaranperusahaan, pihak bawahan cenderung melakukannya dengan mengabaikan faktor etis dan tidaketis. Ketika menyampaikan perintah atau arahan, atasan seringkali menggunakan intensi tekanan bahkan penggunaan kuasa untuk membuat pekerjaanterselesaikan. 


\section{Uji Hipotesis 2}

\section{a. Hipotesis}

Ho : Budaya organisasi tidak memoderasi hubungan antara Tekanan ketaatan terhadap budgetary slack

Ha : Budaya organisasi memoderasi hubungan antara Tekanan ketaatan terhadap budgetary slack

\section{b. Dasar Pengambilan Keputusan}

P-Value $\geq 0.05$, maka Ho di tolak

P-Value $<0.05$, maka Ho di totaldan Ha diterima.

\section{c. Keputusan}

P-Value $=0.022<0.05$ maka Hoditolak dan Ha diterima

\section{d. Kesimpulan dan Pembahasan}

Kesimpulan dari uji hipotesis 2adalah variabel Budaya Organisasi memoderasi hubungan Tekanan ketaatan terhadap budgetary slack. Budaya organisasi dianggap mampu mempengaruhi terjadinya budgetary slack setelah terjadinyatekanan.Ketika atasan memerintahkan atau memberi arahan pada bawahan untukmelakukan sesuatu pada anggaran perusahaan, bawahan kebanyakan akan melaksanakan tanpa bertanya karena kentalnya budaya organisasi yang dianut di perusahaan. Budaya organisasi tersebut salah satunya adalah apapun yang diperintahkan oleh pihak yang posisinya lebih tinggi harus dilaksanakan karenaapabila tidak, maka akan ada pengenaan sanksi dan hukuman lain dalam perusahaan yang bahkan bisa berujung pada pemecatan. Kuatnya tekanan ditambah dengan penerapan budaya organisasi yang kurang menjunjung etika dalam bisnis, menyebabkan budgetary slack lebih mudah terjadi di berbagai skala dan jenis perusahaan.

\section{KESIMPULAN}

Berdasarkan pengujian yang telah dilakukan, kesimpulannya adalah variabel tekanan ketaatan memiliki pengaruh yang signifikan pada terjadinya budgetary slack di perusahaan. Selain kuatnya tekanan ketaatan, budaya organisasi juga terbukti mampu memoderasi hubungan antara tekanan ketaatan terhadap budgetary slack. Tekanan ketaatan yang digabungkan denganbudaya organisasai yang kental pada kebiasaan bahwa perintah atasan adalah sebuah mandat yang harus dilakukan menjadikan praktek budgetary slack jadi mudah terjadi daripada bawahan menerima risiko yang mengancam posisinya di perusahaan.

\section{DAFTAR PUSTAKA}

Agustina, H., Elfita, R., Soelistya, D., Muttaqiin, N \& Mochklas, M. (2021).The role of corporate governance inearnings persistence: Auditcommittee as a moderation variable. Accounting, 7(7), 1779-1784.

Anthony, R. \& Govindarajan., V., 2007. Management Controls System.Boston: Mc GrawHill Co.

Davis, S., DeZoort, F. T. \& Kopp, L. S., 2006. The Effect of Obedience Pressure and PerceivedResponsibility on ManagementAccountants' Creation of Budgetary Slack. Behavioral Research In Accounting, Volume 18, pp. 19-35.

DeZoort, F. T. \& Lord, A. T., 1994. An investigation of obedience pressure effects on auditors' judgments. Behavioral 
Research in Accounting, Volume 6, pp. 1-30.

Dunk, A. \& Nouri, H., 1998. Antecedentsofbudgetary slcak: A literaturereviewand synthesis. Journal of Accounting Literature, Volume 17, pp. 72-96.

Ghozali, I., 2016. Aplikasi Analisis Multivariate dengan Program IBMSPSS. 8 ed. Semarang: Semarang Badan Penerbit Universitas Diponegoro.

Hartanto, H. Y. \& Kusuma, I. W., 2001. Analisis Pengaruh Tekanan Ketaatan Terhadap Judgment Auditor. Jurnal Akuntansi Manajemen.

Hartmann, F. G. H. \& Maas, V. S., 2010. Why business unit controllers create budget slack: Involvement inmanagement, social pressure, and Machiavellianism.BehavioralResearch in Accounting, 2(22), pp. 27-49.

Hobson, J. L., Mellon, M. J. \& Stevens, D. E., 2011. Determinants of moral judgments regarding budgetary slack: An experimental examination of pay scheme and personal values.Behavioral Research in Accounting,1(23), pp. 87107.

Homayoun, S. d. S., 2015. Agency Theory and Corporate Governance. International BussinessManagement, 9 (5)(ISSN: 1993- 5250), pp. 805-815.

Kameliawati, M., 2013. Analisis Pengaruh Partisipasi Anggaran,Informasi Asimetri, Budaya dan Komitmen Organisasi Terhadap Budgetary Slack Pada Rumah Sakit Di Kabupaten Wonogiri, Surakarta: Fakultas Ekonomi dan Bisnis Universitas MuhammadiyahSurakarta.

Khusnah, H., \& Agustina, H. (2019). Dampak Mediasi Moral Reasoning Pada Pengaruh
Organizational Ethical Culture Terhadap Kecenderungan KecuranganAkuntansi. Accounting andManagement Journal, 3(2), 69-76.

Lukka, K., 1988. Budgetary biasing in organizations:Theoretical framework and empirical evidence. Accounting, Organizations and Society, 3(13), pp. 281-301.

Merchant, K., 1985. Budgeting and the propensity to create slack. Accounting Organization and Society, Volume 10, pp. 201-210.

Muttaqi'in, N., \& Katias, P. (2021). Strategies to Improve Service Quality With House of Quality at Hotel $X$ Surabaya. Business and Finance Journal, 6(1), 65-70.

Muttaqiin, Ninnasi. (2016). “Analisis Kebijakan Deviden DI Indonesia Tahun 2013-2017". Accounting and Management Journal, Vol. 3 No.1, July 2019.

Sugiono, 2018. Metodologi penelitian Kuantitatif Kualitatif dan R\&D. Bandung: Alfabeta.

Sugiwardani, R., 2012. Analisis Pengaruh Partisipasi Anggaran, Informasi Simetris, Budaya dan Komitmen Organisasi Terhadap Budgetary Slack, Surabaya: Artikel Ilmiah. Surabaya: Sekolah Tinggi Ilmu Ekonomi Perbanas.

Utami, R. F. S., 2012. Pengaruh Interaksi Budaya Organisasi, dan Group Cohesiveness dalam Hubungan antara Partisipasi Penganggaran dan Senjangan Anggaran (Studi Empiris Pada Instansi Pemerintahan (SKPD) Kabupaten Dharmasraya), Padang: Universitas Negeri Padang. 
Windiani, L. P., Sujana, E. \& Yasa, I. N. P., 2018. Pengaruh Partisipasi Penyusunan Anggaran, Asimetri Informasi, Komitmen Organisasi dan Budaya Organisasi terhadap Potensi Timbulnya Budgetary Slac(Studi Kasus pada SKPD di Kabupaten Bangli). JIMAT (Jurnal Ilmiah Mahasiswa Akuntansi) , 9(e- ISSN: 2614-1930).

Young, S. M., 1985. Participative budgeting: The effects of risk aversion and asymmetric information on budgetary slack. Journal of Accounting Research, 2(23), pp. 829-842.

Yuhertiana, I., 20011. Menggali Peluang Baru Penelitian Di Ranah Akuntansi Keperilakuan Sektor Publik, Surabaya: Seminar Implementasi Sistem Manajemen ISO 90001-2008 da IWA 2 dalam upaya meningkatkan kualitas dosen dan mahasiswa Fakultas Ekonomi dan Bisnis UPN "Veteran" Jawa Timur. 